University of Nebraska - Lincoln

DigitalCommons@University of Nebraska - Lincoln

1988

\title{
World Review of the Parasitoids of the Southern Green Stink Bug, Nezara viridula (L.) (Heteroptera: Pentatomidae)
}

Walker Jones

U.S. Department of Agriculture

Follow this and additional works at: https://digitalcommons.unl.edu/entomologyother

Part of the Entomology Commons

Jones, Walker, "World Review of the Parasitoids of the Southern Green Stink Bug, Nezara viridula (L.) (Heteroptera: Pentatomidae)" (1988). Entomology Papers from Other Sources. 70.

https://digitalcommons.unl.edu/entomologyother/70

This Article is brought to you for free and open access by the Entomology Collections, Miscellaneous at DigitalCommons@University of Nebraska - Lincoln. It has been accepted for inclusion in Entomology Papers from Other Sources by an authorized administrator of DigitalCommons@University of Nebraska - Lincoln. 


\title{
World Review of the Parasitoids of the Southern Green Stink Bug, Nezara viridula (L.) (Heteroptera: Pentatomidae)
}

\author{
WALKER A. JONES' \\ European Parasite Laboratory, U.S. Department of Agriculture, \\ Agricultural Research Service, 13-17 Rue de la Masse, \\ Behoust 78910 Orgerus, France
}

\begin{abstract}
Ann. Entomol. Soc. Am. 81(2): 262-273 (1988)
ABSTRACT A survey of published and unpublished information was used to compile a list of insect parasitoids recorded emerging from Nezara viridula (L.) in the field worldwide. Fifty-seven species among two families of Diptera and five families of Hymenoptera are recorded; 41 are egg parasitoids. No hyperparasitoids are known. Most species are not closely associated with $N$. viridula, although some are well adapted and the status of others is unclear. Six species of Nearctic and Neotropical Tachinidae are well adapted to adult $N$. viridula and could become established in new areas; they also attack large nymphs. There are no effective parasitoids specific to nymphs. The scelionid Trissolcus basalis (Wollaston), probably of Old World origin, is the most widespread egg parasitoid and now occurs with $N$. viridula in the New World, coastal Africa, southern Europe, Pakistan, Australia, New Zealand, and some Pacific islands. Unique complexes of egg parasitoids occur in parts of Africa and eastern Asia. Based on the distribution of the genus Nezara and its species' color polymorphs and egg parasitoid complexes, $N$. viridula is considered to be of Ethiopian origin. African and Asian egg parasitoids in the genera Trissolcus, Telenomus, and Gryon, plus six New World Tachinidae, should be considered for establishment against $N$. viridula elsewhere.
\end{abstract}

KEY WORDS Insecta, Nezara viridula, parasitoids, biological control

THE SOUTHERN green stink bug, Nezara viridula (L.), is one of the most important insect pests of agricultural crops in the world. Its high vagility and polyphagous feeding habits, combined with passive spread via international commerce, have enabled the insect to become widely established around the world. It presently occurs in most of the warmer regions, damaging a wide variety of fruit, nut, grain, and vegetable crops (DeWitt \& Godfrey 1972, Todd \& Herzog 1980). With the expansion of soybean production in the warmer regions of the Americas during the last two decades, and of other crop hosts elsewhere, N.viridula has become the focus of intensified research on control measures. The insect invaded California's Sacramento Valley in 1986 and now poses a serious threat to several crops throughout the state (Hoffman et al. 1987). As cropping patterns of susceptible cultivated plants change, $N$. viridula will continue to become increasingly important worldwide.

Because it is a known emigrant to areas outside Africa and eastern Asia, there have been several attempts to establish parasitoids in newly invaded areas, primarily in the Pacific Basin (Wilson 1960, Rao et al. 1971). The programs in Hawaii and Australia have been considered very successful (DeBach 1962, Clausen 1977, Caltagirone 1981), largely because of the establishment of the egg parasitoid Trissolcus basalis (Wollaston) (Scelioni-

${ }^{1}$ Current address: Biological Control of Insects Laboratory, ARSUSDA, 2000 East Allen Road, Tucson, AZ 85719. dae). Trichopoda pennipes (F.) and T. pilipes $(\mathrm{F}$. (Tachinidae) from the Americas have been released as part of the same projects but have become established only in Hawaii. Clausen (1977) and Luck (1981) have reviewed the various importation programs for which information was available. Classical biological control programs currently are active in the southern United States, Argentina, Chile, Brazil, Taiwan, New Zealand, South Africa, and Cape Verde, Africa.

Both T. basalis and T. pennipes occur with $N$. viridula in the United States, but the host continues to be a major pest where its range overlaps with those of soybean and other susceptible crops. Although attempts have been made to establish new parasitoids in the United States (Lee 1979, Jones et al. 1983, 1985, Jones 1984, Orr 1985), generally the species imported have been the result of fortuitous opportunities rather than the result of organized efforts from classically planned programs.

This paper presents the known parasitoids of $N$. viridula worldwide. The information may suggest new sources of parasitoids for distribution to new areas. Pathogens and predators are not considered here. Native predators are important mortality factors (Panizzi \& Slansky 1985). There are no known records of significant pathogen epizootics in this species. However, searches for pathogens are in progress by Brazil and the United States Department of Agriculture.

The parasitoid species listed include those emerged from field-collected hosts reported in the literature and from unpublished data of my own 
and others. Scientific names reflect the current accepted status for each taxon. The list of known parasitoids (Table 1) is arranged in systematic order and includes geographic range, a brief and somewhat subjective description of known host relations, followed by the most pertinent references.

The text is arranged according to the host stage attacked and is an initial attempt to separate casual associations from those having current and potential use as biological agents against $N$. viridula. The geographic origin of $N$. viridula is also discussed.

\section{Results and Discussion}

Fifty-seven species among two families of Diptera and five families of Hymenoptera are recorded from $N$. viridula worldwide (Table 1). Some of the species names may be synonyms. Parasitoids have been reported from all three life stages.

Egg Parasitoids. Of the five families of Hymenoptera recorded as emerging from the eggs of $N$. viridula, the Scelionidae is the most important. The scelionid, $T$. basalis, is both the most important and the most widely distributed species. It is frequently recorded from several other pentatomids but is clearly most closely associated with $N$. viridula (Cumber 1964, Thomas 1972, Jones 1979, Buschman \& Whitcomb 1980, Ferreira 1980, 1986, Jones 1984, Orr et al. 1984, 1986, Temerak \& Whitcomb 1984). Trissolcus basalis is the dominant egg parasitoid of its primary host in the Americas, the Mediterranean Basin, the Middle East, and Pakistan, and has been established in Hawaii, Australia, New Zealand, and other Pacific islands as part of biological control programs (Lever 1941a, Wilson 1960, Davis 1964, 1967, Rao et al. 1971). Although widely distributed, $T$. basalis appears to be confined primarily to coastal areas within its range. This species was introduced into Taiwan ( $\mathrm{Su} \&$ Tseng 1984) and Argentina (Crouzel \& Saini 1983) from cultures imported from Hawaii and Australia, respectively. Chile recently imported this parasite from Brazil for possible release (E. Zúñiga, personal communication). A culture of $T$. basalis from Morocco has been imported and studied in the U.S.S.R. for comparison with other Trissolcus spp. (Shapiro et al. 1975). Numerous studies have been published on the biology and behavior of $T$. basalis, and research is continuing (Miller 1928, Kamal 1937, Noble 1937, Wilson 1961, Ganesalingam 1966, Thomas 1972, Shapiro et al. 1975, Sales et al. 1978, Powell \& Shepard 1982, and others).

Nine other egg parasitoids have been recorded from N. viridula in the Americas. Telenomus cristatus Johnson (Scelionidae), recently described from N. viridula eggs from Florida and Trinidad (Johnson 1984a), has since been recovered from another pentatomid, Acrosternum hilare (Say), in Louisiana soybeans but not from $N$. viridula eggs in the same fields (Orr et al. 1986). There is no evidence that other New World records indicate more than incidental relationships with $N$. viridula.
Ooencyrtus spp. (Encyrtidae) have been reported from $N$. viridula eggs throughout most of the range of this pentatomid, but are never a major component of the parasitoid complex. Most species are known to have a broad host range within the Heteroptera. Ooencyrtus submetallicus (Howard) occurs in Florida, the West Indies, Brazil, and Argentina (Howard 1898, Myers 1931, Buschman \& Whitcomb 1980, de Santis 1985, Ferreira 1986). This species was imported from the West Indies into Louisiana, Hawaii, Australia, and New Zealand (Wilson 1960, Davis \& Krauss 1963, Davis 1967, Lee 1979), but failed to become established. Lee (1979) concluded that $O$. submetallicus was inferior to $T$. basalis in dispersal and host-finding ability in soybeans in Louisiana.

Four other Ooencyrtus spp., including $O$. malayensis Ferrière, $O$. trinidadensis Crawford, and $O$. nezarae Ishii, have been imported and evaluated in a quarantine facility in the United States and shown to attack at least 20 species of native Pentatomidae, Coreidae, and Rhopalidae (Jones et al. 1983, unpublished data). These species were not released because of their wide host range and lack of evidence of effectiveness in their native regions. Xenoencyrtus rubricatus Riek is known only from a single recovery from $N$. viridula eggs in Australia (Riek 1962). A related species, X. niger Riek, was successfully cultured on $N$. viridula eggs from a single captured female and subsequently reared and released in New Zealand and Hawaii, but has not been recovered from field-collected host eggs (Riek 1962, Davis 1967, Clausen 1977).

Anastatus spp. (Eupelmidae) are only rarely reported from N. viridula. The host range of Anastatus spp. frequently includes more than one insect order. Species that attack $N$. viridula produce only males; females can be produced only in larger host eggs (Hokyo \& Kiritani 1966b, Rao et al. 1971, Genduso 1976, unpublished data). Augmentative releases of an Anastatus sp. are routinely made in China against the lichee stink bug, Tessaratoma papillosa Drury (Tessaratomidae); the parasitoids are mass-produced in large Lepidoptera eggs (MingDau et al. 1974).

Adair (1918) reported the recovery of a Pteromalus sp. (Pteromalidae) from N. viridula in Egypt. Ferriera (1981, 1986) recovered the eurytomid Neorileya sp. in low numbers from $N$. viridula eggs in Brazilian soybeans. Pteromalids and eurytomids have been reported as occasional hyperparasitoids, but there are no records of demonstrated hyperparasitism in $N$. viridula.

A unique complex of Japanese egg parasitoids of $N$. viridula has been studied in detail (Kiritani \& Hokyo 1962, 1970, Hokyo \& Kiritani 1963, 1966a,b, Kiritani et al. 1963, Hokyo et al. 1966, Nakasuji et al. 1966, Kiritani \& Sasaba 1969). Trissolcus mitsukurii (Ashmead) and Telenomus chloropus Thomson (as T. nakagawai Watanabe) occur together in Japan and are important mortality factors of both $N$. viridula and the oriental stink bug, 
Table 1. Parasitoids of the southern green stink bug, Nezara viridula (L.)

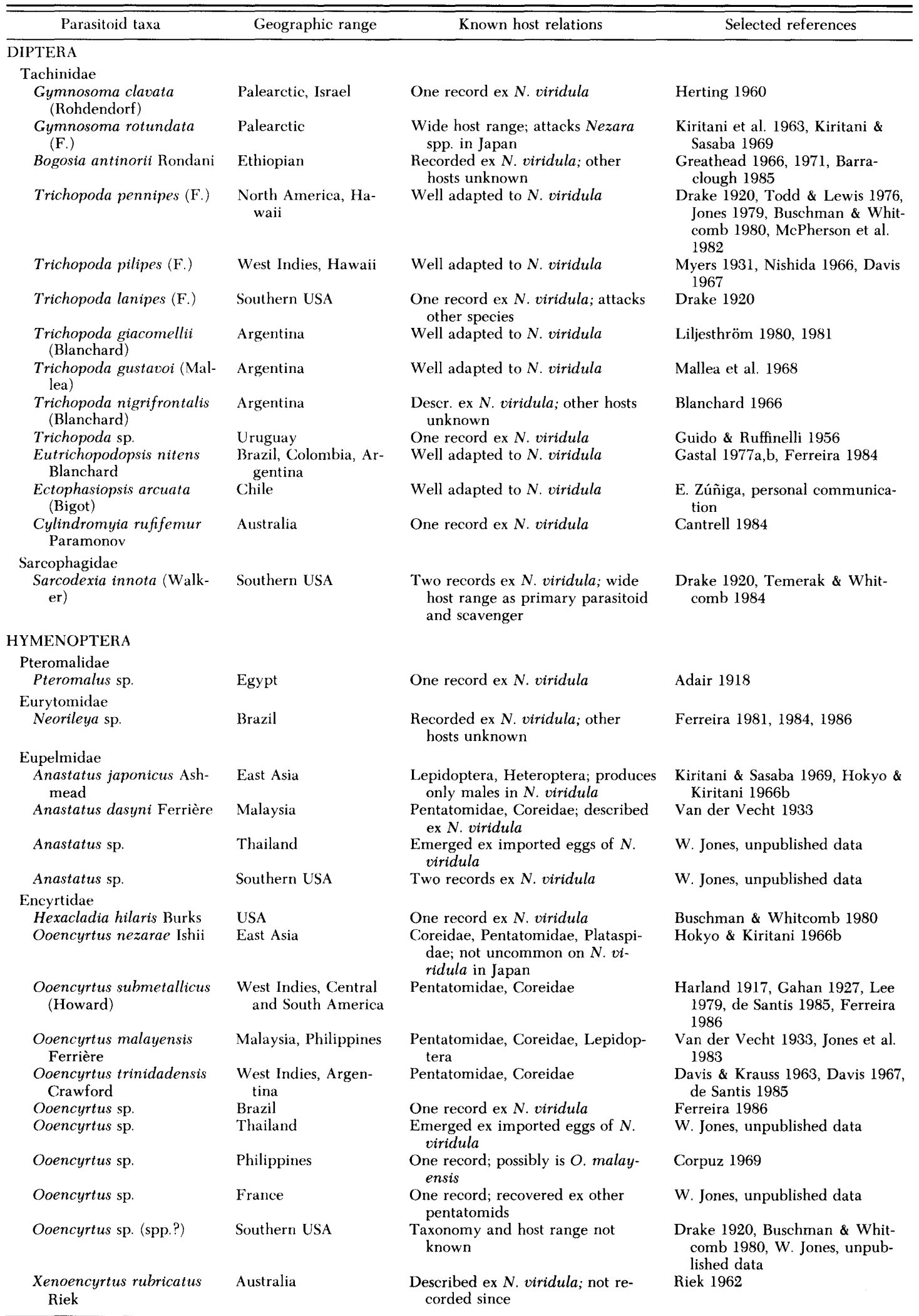


Table 1. Continued

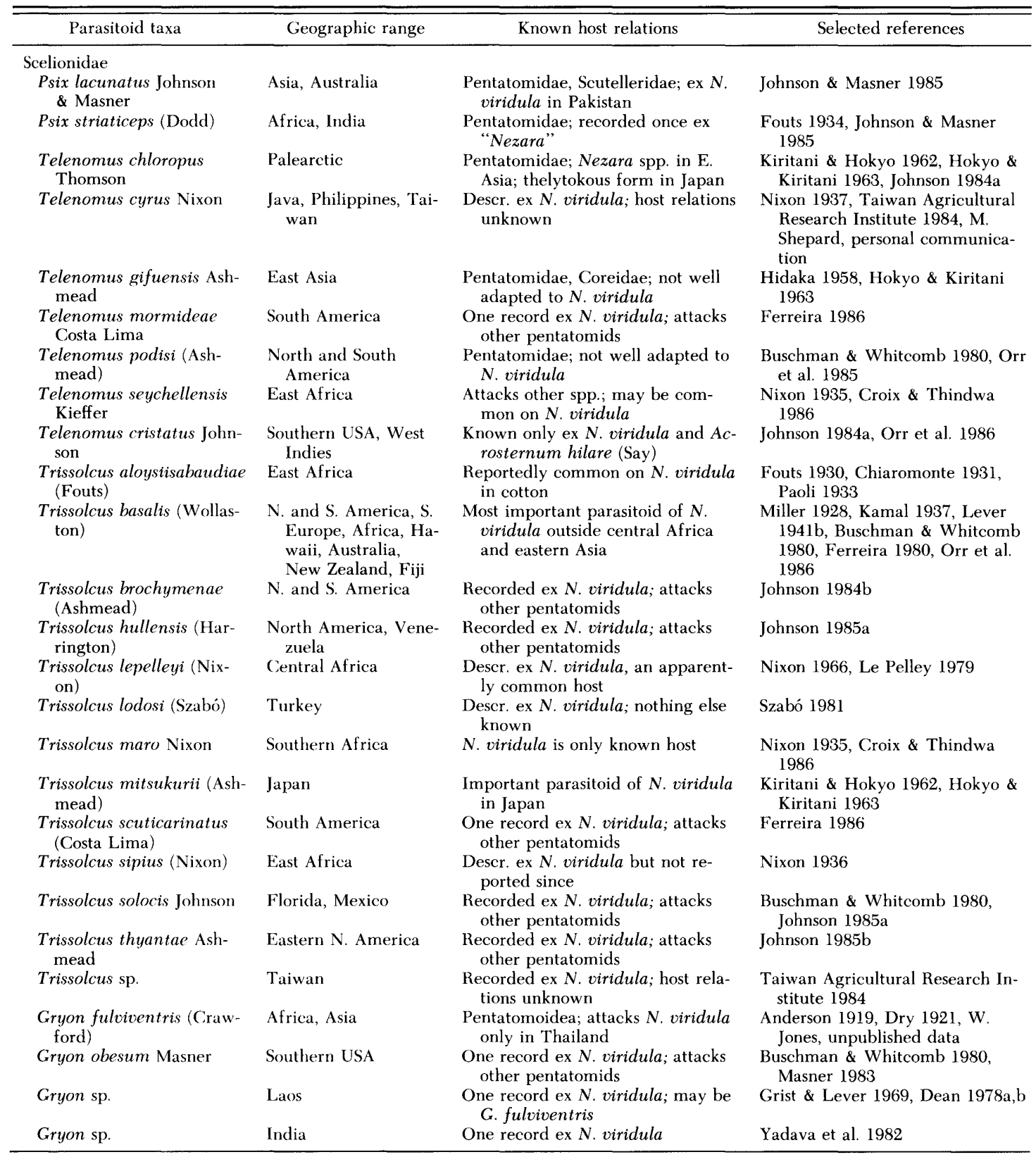

$N$. antennata Scott, in rice. Ooencyrtus nezarae Ishii frequently occurs in low numbers, and Anastatus japonicus Ashmead has been reported from $N$. viridula eggs. Some of the A. japonicus reported by Hokyo et al. (1966) may have been A. gastropachae Ashmead (Y. Hirose, personal communication). Trissolcus mitsukurii is known only from Japan.

The taxonomy of Telenomus chloropus has been discussed recently by Johnson (1984a). T. chloropus is a common polyphagous parasitoid of pentatomid eggs across the Palearctic Region, but it apparently attacks Nezara spp. only in Thailand, Korea, and Japan. The Japanese form is uniquely thelytokous, rarely producing males; the continental populations are arrhenotokous, yet all forms are morphologically similar (Johnson 1984a). In the laboratory, Korean males readily attempt matings with uniparental Japanese females, but the females do not respond and matings are unsuccessful (unpublished data). The Japanese form has been released in Australia (Field 1984), Hawaii (Clausen 1977), and the United States (Jones 1980, Jones et al. 1983, Orr 1985) but has not become established, possibly be- 
cause of its high humidity requirement for successful emergence (Orr et al. 1985). Both T. mitsukurii and $O$. nezarae have recently been imported and released in Brazil (Kobayashi \& Cosenza 1987). The T. basalis reportedly released in Australia from Japan (Clausen 1977) was evidently $T$. mitsukurii. T. Kobayashi (personal communication) has recorded Trissolcus japonicus (Ashmead) and Telenomus hakonensis Ashmead from the eggs of $N$. antennata in Japan, but these parasitoids have not been reported from $N$. viridula.

Thailand has a slightly different complex of egg parasitoids. The most abundant species received in shipments from explorers in Thailand was the scelionid Gryon fulviventris (Crawford), not previously recorded from $N$. viridula (unpublished data). Gryon fulviventris (as Dissolcus fulviventris Mayr, Hadronotus fulviventris (Mayr), H. antestiae Dodd, and G. antestiae (Dodd), all synonymized by Mineo 1979) occurs from Africa through India, Thailand, southern U.S.S.R., and Malaysia, where it has been recorded from many species of Pentatomidae, Scutelleridae, and Coreidae but never previously from Nezara spp. Whitfield \& Cameron (1932) reported that African G. fulviventris readily parasitized and developed in Nezara eggs but adults could not emerge successfully. Eggs of both $N$. viridula and Piezodorus hybneri (Gmelin) imported from Thailand were heavily parasitized by G. fulviventris (unpublished data). The parasitoid should be of interest in South America where $P i$ ezodorus guildinii Westwood, together with N. viridula, seriously damage soybeans but do not share the same native egg parasitoids. As with $T$. chloropus, biotypes evidently exist across the broad geographic range of $G$. fulviventris. The eggs from Thailand also were parasitized by $T$. chloropus, $O$. nezarae, and Anastatus sp. (Jones et al. 1983, unpublished data). The Gryon sp. reported from $N$. viridula eggs in Laos (Grist \& Lever 1969, Dean 1978a,b) and India (Yadava et al. 1982) may be $G$. fulviventris.

Telenomus cyrus Nixon (1937) was described from specimens emerged from a $N$. viridula egg mass collected in Java and has recently been collected from N. viridula eggs in the Philippines (M. Shepard, personal communication). Telenomus cyrus was the most important egg parasitoid of $N$. viridula in soybean, jute, and rice in central Taiwan (Taiwan Agricultural Research Institute 1984). Maximal parasitism was $19 \%$ in soybean, $0.1 \%$ by a Trissolcus sp.

Telenomus gifuensis Ashmead, a common parasitoid of several Japanese pentatomids, has been recovered from $N$. viridula eggs (Kiritani \& Sasaba 1969). Similarly, Telenomus podisi Ashmead in eastern North America, a common egg parasitoid of many North American pentatomids, has been recorded emerging from $N$. viridula eggs (Buschman \& Whitcomb 1980, Orr et al. 1985, unpublished data). Field-collected egg masses that have yielded $T$. podisi usually also yield $T$. basalis in larger numbers (Orr et al. 1984, 1986). Both Te. lenomus spp. rarely emerge from $N$. viridula egg: exposed in the laboratory (Thames 1954, unpublished data).

At least six Scelionidae have been described or recorded from $N$. viridula eggs in Africa. These parasitoids include Trissolcus aloysiisabaudiae (Fouts), T. basalis, T. lepelleyi (Nixon), T. maro (Nixon), T. sipius (Nixon), and Telenomus seychellensis Kieffer. Croix \& Thindwa (1986), in the only study of egg parasitoids of $N$. viridula in Africa, reported an average of $74 \%$ parasitism in Malawi on macadamia by $T$. maro and $T$. seychellensis. This is the first mention of T. maro since its description by Nixon (1935) from southern Africa. Paoli (1933) reported that T. alloysiisabaudiae was very common on $N$. viridula eggs in Somalia, completely destroying many egg masses. Both $T$. lepelleyi and T. sipius were described from $N$. viridula eggs in East Africa. During 1961, $T$. seychellensis and G. fulviventris were shipped from Pakistan to both Australia and Trinidad but failed to breed in the laboratory (Rao et al. 1971). The original hosts in Pakistan were not specified.

Psix striaticeps (Dodd) (Scelionidae), known from tropical Africa to India, has been recorded from N. viridula. Psix lacunatus Johnson \& Masner is widely distributed in Asia and Australia and has been recorded from $N$. viridula eggs only in $\mathrm{Pa}$ kistan (Johnson \& Masner 1985). Nothing can be concluded from the other scattered host-parasitoid records.

Nymph Parasitoids. The nymphal stages of Pentatomidae are generally free from significant attack by parasitoids. Certain Braconidae and Stylopidae are recorded as nymph or nymph-adult parasitoids of a few Pentatomidae, but none has been reported from Nezara spp. Hexacladia hilaris Burks (Encyrtidae) has been recovered occasionally from $N$. viridula in the southern U.S. and Puerto Rico (Buschman \& Whitcomb 1980, F. D. Bennett, personal communication). Its only other recorded host is the pentatomid Acrosternum hilare (Burks 1972, Jones 1979).

Six related Diptera (Tachinidae: Phasiinae) in the New World frequently deposit eggs on the larger $N$. viridula nymphs but are better adapted to the adult stage of their hosts (Capelouto 1949, Mallea et al. 1968, Gastal 1977b, Buschman \& Whitcomb 1980, Liljesthröm 1981, Ferreira 1984, and others). These species are discussed below.

Adult Parasitoids. Tachinidae are the only known parasitoids that attack adult $N$. viridula. In Japan, $N$. viridula is parasitized by Gymnosoma rotundata $(\mathrm{F}$.), a widely distributed tachinid in the Palearctic Regions and known from many hosts. Up to $5 \%$ parasitism has been recorded by Kiritani et al. (1963). This species also attacks $N$. antennata in Japan and Korea (Kiritani et al. 1963, unpublished data). Outside of Japan, there are no published records of tachinids regularly attacking $N$. viridula in the Palearctic and Indo-Malayan Regions. Gym- 
nosoma clavata (Rohdendorf) is recorded once from N. viridula in Europe (Herting 1960).

In the Ethiopian Region, $N$. viridula adults are attacked by Bogosia antinorii Rondani. Greathead (1971) referred to an unsuccessful attempt to establish this parasitoid in Australia from specimens collected in Kenya. This tachinid is widespread in eastern and southern Africa and its only recorded host is N. viridula (van Emden 1945, Barraclough 1985).

In the New World, where N. viridula is a known immigrant, it is sometimes heavily attacked by six related species-T. pennipes in the United States; $T$. pilipes in the West Indies; $T$. giacomellii (Blanchard) and T. gustavoi (Mallea et al. 1968) in Argentina; Eutrichopodopsis nitens Blanchard in Argentina, Brazil, and Colombia; and Ectophasiopsis arcuata (Bigot) in Chile. Each of these native parasitoids has successfully exploited an exotic host and each is now more abundant on N. viridula than on native hosts.

Trichopoda pennipes in North America is actually a complex of biotypes or cryptic species. In the east, the native hosts of $T$. pennipes are the squash bug, Anasa tristis DeGeer, several other coreids, and some pentatomids (Arnaud 1978). In California, T. pennipes attacks only a pyhrrhocorid and a largid and will not oviposit on squash bugs (Sabrosky 1955, Dietrick \& van den Bosch 1957). In the southeast, the parasitoid attacks several coreids. It is regularly taken from the native pentatomid Acrosternum hilare and only occasionally from pentatomids other than $N$. viridula (Drake 1920, Schoene \& Underhill 1933, Eaton 1975, Jones 1979, Buschman \& Whitcomb 1980, Eger \& Ables 1981, McPherson et al. 1982, Menezes et al. 1985).

In the West Indies, T. pennipes is replaced by the closely related T. pilipes (Myers 1931, Guimarães 1971, Arnaud 1978). Both species, variously reported as T. pennipes or T. pennipes pilipes $(\mathrm{F}$.$) ,$ have been imported into Hawaii, Australia, and other Pacific islands for attempted establishment against $N$. viridula (O'Conner 1950, Wilson 1963, Davis 1967, Michael 1981). Both species are now established in Hawaii, but T. pilipes is more important (Davis 1967). South Africa has recently imported T. pennipes from Florida for attempted establishment (F. D. Bennett, personal communication).

Eutrichopodopsis nitens is an important parasitoid of N. viridula in Brazil and parts of Argentina; its biology and host relations are similar to those of the previous two species (Gastal 1977a,b, Ferreira 1984). Trichopoda giacomellii was recorded parasitizing $100 \%$ of $N$. viridula adults for three consecutive generations in an uncultivated area near Buenos Aires (Liljesthröm 1981). Ectophasiopsis arcuata regularly attacks $N$. viridula in Chile and has successfully been established on this host on Easter Island (E. Zúñiga, personal communication).

Two other tachinids, Trichopodopsis nigrifron- talis Blanchard (1966) in Argentina and Cylindromyia rufifemur Paramonov (1956, cited by Cantrell 1984) in Australia, have been described from adults reared from $N$. viridula but have not subsequently been reported from this host. Trichopoda lanipes ( $\mathrm{F}$.) has been recorded once from $N$. viridula in Florida (Drake 1920). The identity of Trichopoda sp. recorded from N. viridula in Uruguay (Guido \& Ruffinelli 1956) is unknown. Panizzi \& Slansky (1985) refer to other tachinids recorded from N. viridula in Brazil by Lima (1940) and Silva et al. (1968), but I was unable to see these publications.

\section{Origin of $N$. viridula}

The southern green stink bug is assumed to have originated from the eastern Palearctic or Indo-Malayan Regions (Yukawa \& Kiritani 1965, Kiritani 1971, DeWitt \& Godfrey 1972, Todd \& Herzog 1980). Based on Freeman's (1940) review of the known Nezara spp., Jones \& Powell (1982) suggested that the Ethiopian Region was more likely the area of origin. Following a further examination of other species in the genus Nezara and the distributions of $N$. viridula polymorphs and closely associated parasitoids, I propose that $N$. viridula is of Ethiopian origin.

Freeman (1940) recognized 10 species and several distinct color forms in Nezara: the cosmopolitan $N$. viridula, the oriental $N$. antennata, and eight species confined to continental Africa and Madagascar. Azim \& Shafee (1978) have described a new species from India closely related to an African Nezara; they provided a new key to the eleven species. L. R. Rolston (personal communication) presently considers 20 species names to be valid, with all but seven confined to Africa. Although an historical-biogeographical analysis of the genus Nezara would help pinpoint the origin of the genus, the fact that the bulk of the species in the genus are African tends to discount a southeast Asian point of radiation.

Adult $N$. viridula have distinct genetically controlled color polymorphs that occur together in varying ratios in various regions (Freeman 1940, Servadei 1967, Kiritani 1970, Singh 1973, Schmitz 1978, and others). Based on an analysis of the frequency distribution of these polymorphs, Yukawa \& Kiritani (1965) concluded that the insect probably originated from southeastern Asia. The presence of a unique complex of effective parasitoids tends to support their conclusion. However, they overlooked the work of others showing evidence of the significant occurrence of the same polymorphs in other areas of the world. Furthermore, all or nearly all African Nezara spp. also possess each of the polymorphs recorded in East Asian $N$. viridula. Most, if not all, color polymorphs commonly occur in $N$. viridula populations from subSaharan Africa through the Mediterranean Basin 
east to China (Freeman 1940, Servadei 1967, Singh 1973, Schmitz 1978, Chen 1980, Singh \& Rawat 1982, and others). All but one of the African Nezara species reviewed by Freeman possess similar polymorphs and some may have additional morphs not known in $N$. viridula. Only in areas where $N$. viridula is a known invader, such as the Americas, Australia, and certain Pacific islands, are some of the major polymorphs not similarly represented.

The present review of the parasitoids of N. viridula shows that those species most closely associated with this host (excluding the adapted tachinids in America) are generally concentrated in Japan and Africa, each region possessing completely different complexes. Outside these regions, $N$. viridula is parasitized by native, adventive, or introduced species. Trissolcus basalis is well established in the Americas, probably via parasitized egg masses among imported plant material. This species is the most important parasitoid of N. viridula outside most of Africa and Asia and, although it is sometimes recovered from the eggs of other pentatomids, it does not occur outside the geographic range of its primary host. Johnson (1985a) noted that New World specimens of $T$. basalis showed much less morphological variation than those from Africa, an indication of an Old World if not an African origin.

Between the eastern Mediterranean and China, the little information available shows that a variety of species of Psix, Trissolcus, Telenomus, Gryon, and Ooencyrtus have been reported from N. viridula eggs, but there is no distinguishable pattern or a defined complex in any one area. Trissolcus lodosi was recently described from $N$. viridula eggs in Turkey (Szabó 1981), but little or nothing is known about this species or other parasitoids from Greece, Asia Minor, and the Middle East. A Pakistan strain of $T$. basalis has been imported and established in Australia (Wilson 1963) and the polyphagous and widespread $P$. lacunatus has been recorded from $N$. viridula there (Johnson \& Masner 1985). The original hosts of the $T$. seychellensis and $G$. fulviventris shipped from Pakistan for release against $N$. viridula in the West Indies and Australia (Rao et al. 1971) were not reported. Because neither species was successfully reared in the laboratory, the two parasitoids may have been collected from other hosts. Singh (1973) reported no parasitoids in life-table studies of $N$. viridula in India.

In Africa, there are at least six Scelionidae known to be associated with $N$. viridula-Trissolcus aloysiisabaudiae, T. basalis, T. lepelleyi, T. maro, $T$. sipius, and Telenomus seychellensis. Although $T$. seychellensis is known from other African pentatomids, it and T. maro are important natural control agents of $N$. viridula in Malawi (Croix \& Thindwa 1986), whereas $T$. lepelleyi is its normal parasitoid in Kenya (Le Pelley 1979). Trissolcus aloysiisabaudiae is important on N. viridula in cotton in Somalia (Chiaromonte 1931, Paoli 1933).
Trissolcus sipius is known only from $N$. viridula eggs in Kenya. Trissolcus basalis is distributed only along coastal areas, whereas the others have been reported primarily from the central and eastern half of the continent. Although T. basalis has been imported into South Africa from New Zealand, Australia, and recently from the United States, there is evidence that it already occurred there prior to importations (Giliomee 1958, Greathead 1971).

The occurrence of $N$. viridula in Japan may be a modern phenomenon, and the presence of unique, well-adapted egg parasitoids may have evolved through long association there with the closely related oriental stink bug, $N$. antennata. The first record of $N$. viridula in Japan was in 1879 (the first New World record was in 1798), but the insect was not recorded again until found in mixed populations with N. antennata in 1952 (Hasegawa 1954), and it did not become a pest until about 1955 (Kiritani 1971). Clausen (1931) listed N. viridula as an agricultural pest in Japan, but the species was more likely the almost identical $N$. antennata, which was not listed. Kiritani et al. (1963) have documented the modern replacement of $N$. antennata by N. viridula in parts of Japan, attributing the phenomenon to changing rice cultivation practices and competitive displacement through interspecific matings. At present, N. antennata in Japan is confined primarily to colder latitudes and higher elevations where N. viridula is poorly adapted for survival, yet the parasitoids shared among both Nezara spp. occur throughout the range of each. Cultures from two shipments of T. mitsukurii imported from Japan were each lost by the third generation, apparently due to failure of adequate numbers of adult parasitoids to emerge successfully from the eggs in the laboratory (unpublished data). In Brazil, Kobayashi \& Cosenza (1987) compared acceptance and successful emergence of an indigenous population of $T$. basalis with Japanese $T$. mitsukurii. Their results showed that $T$. basalis parasitized about $90 \%$ of exposed N. viridula eggs, with $60 \%$ successful adult emergence, compared with about $70 \%$ parasitism by $T$. mitsukurii and $40 \%$ emergence.

\section{Summary and Conclusions}

Although 57 parasitoids are recorded as using $N$. viridula as a host, many of these associations are incidental; either some species are rare or they are more closely associated with other hosts or habitats. No nymphal parasitoids are well adapted to $N$. viridula.

No known effective parasitoids of adult $N$. viridula are known outside the Western Hemisphere. In the Americas, at least six tachinids have become well adapted to $N$. viridula since it became established about two centuries ago-Trichopoda pennipes in the United States, T. pilipes in the West Indies, and T. giacomellii, T. gustavoi, E. nitens, and E. arcuata in South America. The biologies of 
these tachinids are apparently similar, and each species is closely associated with $N$. viridula within their respective geographic ranges (Nishida 1966, Mallea et al. 1968, Shahjahan \& Beardsley 1975, Gastal 1977a,b, Liljesthröm 1981, Harris \& Todd 1982, Ferreira 1984). Both $T$. pennipes and $T$. pilipes have been successfully established against $N$. viridula in Hawaii; $T$. pilipes is the more effective species (Davis 1967). The role of Bogosia antinorii on $N$. viridula in Africa requires further investigation.

The American tachinids should be able to exert some degree of pressure on $N$. viridula populations in Africa and Asia where this pentatomid is also a pest. Hokkanen (1983) recently concluded that, after an estimated 150-200-yr association with $T$. pennipes in the New World, Florida populations of $N$. viridula have evolved a $10 \%$ better reproductive success in resisting attack than host populations from Italy not previously exposed to this parasitoid. A comparative study of the six trichopodine tachinids should be made to determine which species would be the most effective if established in previously unexposed host populations.

Egg parasitoids are the most important biocontrol agents of $N$. viridula. There are 41 species among five families of Hymenoptera recorded emerging from $N$. viridula eggs. Like some of the species reported attacking nymphs and adults, several egg parasitoids have been recorded only once, and some undoubtedly are poorly adapted to $N$. viridula. Others are evidently well adapted but have not been investigated. The taxonomy and biosystematics of the African Trissolcus spp. need to be studied.

The Ethiopian Region is proposed as the origin of N. viridula, and an ecological evaluation of parasitoids there is highly warranted. The present examination of world parasitoids of $N$. viridula clearly shows that several untried sources remain for introduction and establishment for enhanced biological control of $N$. viridula in the world.

\section{Addendum}

Following acceptance of this manuscript, I found that Hokkanen (1986) had published a similar paper with similar conclusions. His list of 27 parasitoids included three species referred to by Herting (1971) and not listed here in Table 1: the tachinid Gymnosoma kuramanum Matsumura in Japan (Takano 1956), the encyrtid Ooencyrtus fecundus Ferrière \& Voegelé in Morocco (Voegelé 1961), and the eulophid Pleurotropitiella albipes Blanchard in Argentina (Esquivel 1950).

Hokkanen also found that $N$. viridula probably originated from the Ethiopian Region, basing his conclusion on an examination of the distribution of closely associated parasitoids, the frequency of occurrence of color polymorphs, and the distribution of other species of Nezara. These results add further evidence that future classical biological control programs against the southern green stink bug should be based on a thorough examination of African parasitoids as the most likely candidates for establishment in other areas.

\section{Acknowledgment}

I thank F. D. Bennett, F. Bin, N. F. Johnson, T. J. Poprawski, and J. E. Powell for reviewing early drafts. I also appreciate the help of the following for contributing unpublished information and exotic parasitoid material-F. D. Bennett (University of Florida), D. J. Greathead (CAB International, Imperial College, U.K.), N. F. Johnson (Ohio State University), W. W. Harrison (ARSUSDA, Stoneville, Miss.), K. Kiritani (MAFF, Tsukuba, Japan), T. Kobayashi (TARC, Tsukuba, Japan), M. Kogan (University of Illinois), B. M. Shepard (IRRI, Manila, Philippines), S. G. Turnipseed (Clemson University), E. Zúñiga (IIA, Quillota, Chile), Y. Hirose (Kyushu University, Fukuoka, Japan), and L. H. Rolston (Louisiana State University). Certain identifications and verifications of scientific names were made by specialists associated with the Systematic Entomology Laboratory, USDA-ARS, Beltsville, Md.

\section{References Cited}

Adair, E. W. 1918. Preliminary list of insects associated with cotton in Egypt. Agric. J. Egypt 8: 80-88.

Anderson, T. J. 1919. The coffee bug. Antestia lineaticollis, Stal. Bull. Brit. E. Afr. Dep. Agric. 1.

Arnaud, P. H., Jr. 1978. A host-parasite catalog of North American Tachinidae (Diptera). U.S. Dep. Agric. Misc. Publ. 1319.

Azim, M. N. \& S. A. Shafee. 1978. Indian species of the genus Nezara Amyot and Serville (Hemiptera: Pentatomidae). J. Bombay Nat. Hist. Soc. 75: 507511.

Barraclough, D. A. 1985. The Afrotropical genus Bogosia Rondani, 1873 (Diptera: Tachinidae). Ann. Natal Mus. 26: 339-376.

Blanchard, E. E. 1966. Nuevos triquiopodinos argentinos, parásitos de hemípteros nocivos (Dipt. Gymnosomatidae). Rev. Invest. Agropecu., Ser. 5, 3: 5997.

Burks, B. D. 1972. The genus Hexacladia Ashmead (Hymenoptera: Encyrtidae). Proc. Entomol. Soc. Wash. 74: 363-371.

Buschman, L. L. \& W. H. Whitcomb. 1980. Parasites of Nezara viridula (Hemiptera: Pentatomidae) and other Hemiptera in Florida. Fla. Entomol. 63: 154167.

Caltagirone, G. B. 1981. Landmark examples in classical biological control. Annu. Rev. Entomol. 26: 213232.

Cantrell, B. K. 1984. Synopsis of the Australian Phasinae, including revisions of Gerocyptera Townsend and the Australian species of Cylindromyia Meigen (Diptera: Tachinidae). Aust. J. Zool. Suppl. Ser. 102.

Capelouto, R. 1949. Some studies on the parasitic relationship between the feather-legged tachina fly, Trichopoda pennipes Fab. and the southern green stink bug, Nezara viridula Linne. J. Newell Entomol. Soc. 4: 31-33.

Chen, F. 1980. A new form of Nezara viridula (Linnaeus). Entomotaxonomia 2: 31-32 (in Chinese, with English summary).

Chiaromonte, A. 1931. Note intorno alla biologia de- 
gli insetti più importanti per la coltivazione del cotone nella Somalia Italiana. Atti l Congr. Colon., Firenze 1931.

Clausen, C. P. 1931. Insects injurious to agriculture in Japan. U.S. Dep. Agric. Circ. 168.

1977. Introduced parasites and predators of arthropod pests and weeds: a world review. U.S. Dep. Agric., Agric. Handb. 480.

Corpuz, L. R. 1969. The biology, host range, and natural enemies of Nezara viridula L. (Pentatomidae, Hemiptera). Philipp. Entomol. 1: 225-239.

Croix, E. A. S. La \& H. Z. Thindwa. 1986. Macadamia pests in Malawi. III. The major pests. The biology of bugs and borers. Trop. Pest Manag. 32: 11-20.

Crouzel, I. S. de \& E. D. Saini. 1983. Importación de Trissolcus basalis (Wollaston) (Hym. Scelionidae) en la Argentina para el control biologico de Nezara viridula (L.) (Hem. Pentatomidae). Rev. Soc. Entomol. Argent. 42: 257-260.

Cumber, R. A. 1964. The egg-parasite complex (Scelionidae: Hymenoptera) of shield bugs (Pentatomidae, Acanthosomidae: Heteroptera) in New Zealand. N.Z J. Sci. 7: 536-554.

Davis, C. J. 1964. The introduction, propagation, liberation, and establishment of parasites to control $\mathrm{Ne}$ zara viridula variety smaragdula (F.) in Hawaii (Heteroptera: Pentatomidae). Proc. Hawaii. Entomol. Soc. 18: $369-376$.

1967. Progress in the biological control of the southern green stink bug, Nezara viridula variety smaragdula (Fabricius) in Hawaii (Heteroptera: Pentatomidae). Mushi 3: 9-16 (suppl.).

Davis, C. J. \& N. L. H. Krauss. 1963 . Recent introductions for biological control in Hawaii-VIII. Proc. Hawaii. Entomol. Soc. 18: 245-249.

Dean, G. J. 1978a. Insects found on economic plants other than rice in Laos. PANS 24: 129-142.

1978b. Insect pests of rice in Laos. PANS 24: 280 289.

DeBach, P. 1962. An analysis of success in biological control of insects in the Pacific area. Proc. Hawaii. Entomol. Soc. 18: 69-79.

de Santis, L. 1985. Dos notas sobre Himenopteros Calcidoideos parasitoides oofagos de Hemipteros Heteropteros (Insecta). Rev. Chil. Entomol. 12: 9194

DeWitt, N. B. \& G. L. Godfrey. 1972. The literature of arthropods associated with soybeans II. A bibliography of the southern green stink bug Nezara viridula (Linnaeus) (Hemiptera: Pentatomidae). Ill. Nat. Hist. Surv. Biol. Notes 78.

Dietrick, E. J. \& R. van den Bosch. 1957. Insectary propagation of the squash bug and its parasite Trichopoda pennipes Fabr. J. Econ. Entomol. 50: 627-629.

Drake, C. J. 1920. The southern green stink-bug in Florida. Fla. State Plant Board Q. Bull. 4: 41-94.

Dry, F. W. 1921. The egg parasites of the coffee bug (Antestia lineaticollis, Stål) in Kenya Colony. Bull. Entomol. Res. 12: 191-201.

Eaton, A. T. 1975. Biological control agents of soybean insect pests in the tidewater area of Virginia. M.S. thesis, Virginia Polytechnic Institute and State Univ., Blacksburg.

Eger, J. R., Jr., \& J. R. Ables. 1981. Parasitism of Pentatomidae by Tachinidae in South Carolina and Texas. Southwest. Entomol. 6: 28-33.

Esquivel, L. 1950. Primer suplemento a la lista de Himenopteros parasitos y predatores de los insectos de la Republica Argentina. Rev. Soc. Entomol. Argent. 14: 270-296 (not seen, vide Hokkanen [1986]).
Ferreira, B. S. C. 1980 . Ocorrência, no Brasil, de Trissolcus basalis, parasita de ovos de Nezara viridula. Pesqui. Agropecu. Bras. 15: 127-128.

1981. Ocorrência de parasitas em ovos e adultos de perçevejos da soja. In 7th Cong. Bras. Entomol., 1217 July, 1981. Fortaleza, Ceara. (abstr.).

1984. Incidência do parasitóide Eutrichopodopsis nitens Blanchard, 1966 em populações do perçevejo verde Nezara viridula (Linnaeus, 1758). Ann. Soc. Entomol. Bras. 13: 321-330.

1986. Ocorrência natural do complexo de parasitóides de perçevejos da soja no Paraná. Ann. Soc. Entomol. Bras. 15: 189-199.

Field, R. P. 1984. The use of predators and parasites in Australian biological control programs, pp. 333343. In Australian Applied Entomology Research Conference, Adelaide, 24-28 September 1984.

Fouts, R. 1930. A new species of Microphanurus from Italian Somaliland (Hym. Scelionidae). Boll. Soc. Entomol. Ital. 62: 118-120.

1934. Report on a small collection of parasitic $\mathrm{Hy}$ menoptera from Italian Somaliland. Mem. Soc. Entomol. Ital. 13: 98-109.

Freeman, P. 1940. A contribution to the study of the genus Nezara Amyot and Serville (Hemiptera, Pentatomidae). Trans. R. Entomol. Soc. Lond. 80: 351371.

Gahan, A. B. 1927. Miscellaneous descriptions of new parasitic Hymenoptera with some synonymical notes. Proc. U.S. Nat. Mus. 71: 1-39.

Ganesalingam, V. K. 1966. Some environmental factors influencing parasitization of the eggs of Nezara viridula L. (Pentatomidae) by Telenomus basalis Wollaston (Hymenoptera: Scelionidae). Ceylon J. Sci. Biol. Sci. 6: 1-14.

Gastal, H. A. de O. 1977a. Observações sobre $E u$ trichopodopsis nitens Blanchard (Diptera, Tachinidae) parasitando Nezara viridula, (L.) (Hemiptera, Pentatomidae). Rev. Bras. Entomol. 20: 153-157.

1977b. Ocorrência de Eutrichopodopsis nitens Blanchard (Diptera, Tachinidae) parasitando Nezara viridula (L.) (Hemiptera, Pentatomidae) no estado do Paraná, Brasil. Rev. Bras. Entomol. 21: 55-61.

Genduso, P. 1976. Difesa del nocciolo dagli artropodi dannosi. IX. Osservazioni sulla morfologia degli stati preimmaginali e notizie bio-etologiche sull'Anastatus bifasciatus (Geoffroy). Boll. Ist. Entomol. Agra. Osserv. Fitopatol. Palermo 9: 1-22.

Giliomee, J. 1958. Green stink-bug in winter rainfall region. Farming S. Africa. 34: 55-56.

Greathead, D. J. 1966. The parasites of Antestiopsis spp. (Hem. Pentatomidae) in East Africa, and a discussion of the possibilities of biological control. Commonw. Inst. Biol. Control Tech. Bull. 7: 113-137.

1971. A review of biological control in the Ethiopian Region. Commonw. Inst. Biol. Control Tech. Commun. 5: 1-162.

Grist, D. H. \& R. J. A. W. Lever. 1969. Pests of rice. Longmans, Green, London.

Guido, A. S. \& A. Ruffinelli. 1956. Primer catálogo de los parásitos y predators encontrados en el Uruguay. Fac. Agron. Montevideo, Uruguay Bol. 32.

Guimarães, J. H. 1971. A catalogue of the Diptera of the Americas south of the United States. 104. Family Tachinidae (Larvaevoridae). Mus. Zool., Univ. Sao Paulo.

Harland, S. C. 1917. Special entomological investigations. St. Vincent Agric. Dep. Rep. 1916-1917: 1011.

Harris, V. E. \& J. W. Todd. 1982 . Longevity and 
reproduction of the southern green stink bug, Nezara viridula, as affected by parasitization by Trichopoda pennipes. Entomol. Exp. Appl. 31: 409-412.

Hasegawa, H. 1954. Notes on Nezara viridula (Linne) and its allied green stink-bug in Japan. Bull. Nat. Inst Agri. Sci. (Japan) Ser. C4: 215-228 (in Japanese).

Herting, B. 1960. Biologie der westpaläarktischen Raupenfliegen Dipt., Tachinidae. Monogr. Angew. Entomol., Beihefte Zeitsch. Angew. Entomol. No. 16. Paul Parey, Hamburg.

1971. A catalogue of parasites and predators of terrestrial arthropods, section A, vol. 1. Commonw. Agric. Bur., Slough, U.K. (not seen, vide Hokkanen [1986]).

Hidaka, T. 1958. Biological investigation on Telenomus gifuensis Ashmead (Hym.: Scelionidae), an eggparasite of Scotinophara lurida Burmeister (Hem. Pentatomidae) in Japan. Acta Hymenopterologica 1: $75-93$.

Hoffman, M. P., L. T. Wilson \& F. G. Zalom. 1987. Control of stink bugs in tomatoes. Calif. Agric. 41: 4-6.

Hokkanen, H. 1983. Interspecific homeostasis, pest problems, and the principle of classical biological pest control. Ph.D. dissertation, Cornell Univ, Ithaca, N.Y.

1986. Polymorphism, parasites, and the native area of Nezara viridula (Hemiptera, Pentatomidae). Ann. Entomol. Fennici 52: 28-31.

Hokyo, N. \& K. Kiritani. 1963. Two species of egg parasites as contemporaneous mortality factors in the egg population of the southern green stink bug, $\mathrm{Ne}$ zara viridula. Jpn. J. Appl. Entomol. Zool. 7: 214226.

1966a. Oviposition behavior of 2 egg parasites, Asolcus mitsukurii and Telenomus nakagawai. Entomophaga 11: 191-201.

1966b. Comparative biology of two scelionid egg parasites of Nezara viridula L. (Hemiptera: Pentatomidae). Appl. Entomol. Zool. 1: 94-102.

Hokyo, N., M. Shiga \& F. Nakasuji. 1966. The effect of intra- and interspecific conditioning of host eggs on the ovipositional behavior of two scelionid egg parasites of the southern green stink bug, Nezara viridula L. Ipn. J. Ecol. 16: 67-71.

Howard, L. O. 1898. On the Chalcididae of the island of Granada in West Indies; Encyrtus submetallicus, sp. n. J. Linn. Soc. Lond. Zool. 26: 151-152.

Johnson, N. F. 1984a. Systematics of Nearctic Telenomus: classification and revisions of the podisi and phymatae species groups (Hymenoptera: Scelionidae). Bull. Ohio Biol. Surv., New Ser. 6: 1-113.

1984b. Revision of the Nearctic species of the Trissolcus flavipes group (Hymenoptera: Scelionidae). Proc. Entomol. Soc. Wash. 86: 797-803.

1985a. Systematics of New World Trissolcus (Hymenoptera: Scelionidae): species related to $T$. basalis. Can. Entomol. 117: 431-445.

1985b. Revision of the New World species of the thyantae group of Trissolcus (Hymenoptera: Scelionidae). Can. Entomol. 117: 107-112.

Johnson, N. F. \& L. Masner. 1985. Revision of the genus Psix Kozlov \& Lê (Hymenoptera: Scelionidae) Syst. Entomol. 10: 33-58.

Jones, W. A. 1979. The distribution and ecology of pentatomid pests of soybeans in South Carolina. Ph.D. dissertation, Clemson Univ., Clemson, S.C.

1980. Stink bug pests of soybeans, p. 15. In 27th Annu. Miss. Contr. Conf. Proc. 1980 (abstr.).

1984. Parasites of the southern green stink bug, p. 18. In Miss. Entomol. Assoc. Proc., vol. 3 (abstr.).

Jones, W. A. \& J. E. Powell. 1982. Potential for biological control of the southern green stink bug on soybeans, pp. 21-22. In Miss. Entomol. Assoc. Proc., vol. 1 (abstr.).

Jones, W. A., S. Y. Young, M. Shepard \& W. H. Whitcomb. 1983. Use of imported natural enemies against insect pests of soybean, pp. 63-77. In H. Pitre [ed.], Natural enemies of arthropod pests in soybean. Southern Coop. Ser. Bull. 285.

Jones, W. A., J. E. Powell \& E. G. King. 1985. Stoneville Research Quarantine Facility: a national center for support of research on biological control of arthropod and weed pests. Bull. Entomol. Soc. Am. 31: $20-26$.

Kamal, M. 1937. The cotton green bug, Nezara viridula L. and its important egg parasite, Microphanurus megacephalus (Ashmead). Bull. Soc. Entomol. Egypte 21: 175-207.

Kiritani, K. 1970. Studies on the adult polymorphism in the southern green stink bug, Nezara viridula (Hemiptera: Pentatomidae). Res. Popul. Ecol. 12: 19-34.

1971. Distribution and abundance of the southern green stink bug, Nezara viridula, pp. 235-248. In Symposium on Rice Insects. Tropical Agriculture Research Center, Tokyo.

Kiritani, K. \& N. Hokyo. 1962. Studies on the life table of the southern green stink bug, Nezara viridula. Jpn. J. Appl. Entomol. Zool. 6: 124-140.

1970. Studies on the population ecology of the southern green stink bug, Nezara viridula L. Agric. Forest. Fish. Res. Counc. Spec. Proj. 9 (in Japanese).

Kiritani, K. \& T. Sasaba. 1969. The differences in bio- and ecological characteristics between neighbouring populations in the southern green stink bug, Nezara viridula L. Jpn. J. Ecol. 19: 178-183.

Kiritani, K., N. Hokyo \& J. Yukawa. 1963. Co-existence of the two related stink bugs, Nezara viridula and $N$. antennata under natural conditions. Res. Popul. Ecol. 5: 11-22.

Kobayashi, T. \& G. W. Cosenza. 1987. Integrated control of soybean stink bugs in the Cerrados. Jpn. Agric. Res. Quart. 20: 229-236.

Lee, S. C. 1979. Evaluation of Ooencyrtus submetallicus (Howard) and Trissolcus basalis (Wollaston) as egg parasites of Nezara viridula (Linnaeus). Ph.D. dissertation, Louisiana State Univ., Baton Rouge.

Le Pelley, R. H. 1979. Some scelionid egg-parasites reared from coffee bugs and from some unusual pentatomid hosts. Entomophaga 24: 255-258.

Lever, R. J. A. W. 1941a. Division of Entomology. Fiji Dep. Agric. Annu. Rep. 1940

1941b. Entomological notes. 1. Egg parasites of the green vegetable bug. Agric. J. Dep. Agric. Fiji Isl. 12: $45-46$.

Liljesthröm, G. G. 1980. Nota sobre Trichopoda giacomellii (Blanchard, 1966) (Diptera, Tachinidae). Neotropica 26: 233-236.

1981. Algunas consideraciones sobre la dinamica poblacional de Nezara viridula (L.) (Hemiptera Pentatomidae) e interacciones con Trichopoda giacomellii (Blanchard, 1966) (Diptera Tachinidae). Tropicana 27: $11-16$

Lima, A. M. C. 1940. Insetos do Brasil: Hemiptera, vol. 2. Escola National de Agricultura, Rio de Janeiro (not seen, vide Panizzi \& Slansky [1985]).

Luck, R. F. 1981. Parasitic insects introduced as biological control agents for arthropod pests, pp. 125284. In D. Pimentel [ed.], Handbook of pest management in agriculture, vol. 2. CRC Press, Boca Raton, Fla.

Mallea et al. 1968. Análisis de una población de $\mathrm{Ne}$ - 
zara viridula (L.) Stal (Hemiptera, Pentatomidae) "Chinche verde de las hortalizas", en relación al grado de parasitismo de Trichopodopsis gustavoi Mallea (Diptera, Gymnostomatidae). Intersectum, Mendosa. 10: 17-20 (not seen, vide Liljesthröm [1981]).

Mani, M. S. \& S. S. K. Sharma. 1982. Proctotrupoidea (Hymenoptera) from India. A review. Oriental Insects 16: 135-258.

Masner, L. 1983. A revision of Gryon Haliday in North America (Hymenoptera: Proctotrupoidea: Scelionidae). Can. Entomol. 115: 123-174.

McPherson, R. M., J. R. Pitts, L. D. Newsom, J. B. Chapin \& D. C. Herzog. 1982. Incidence of tachinid parasitism of several stink bug (Heteroptera: Pentatomidae) species associated with soybean. J. Econ. Entomol. 75: 783-786.

Menezes, E. B., D. C. Herzog \& P. J. d'Almada. 1985. A study of parasitism of the southern green stink bug, Nezara viridula (L.) (Hemiptera: Pentatomidae), by Trichopoda pennipes (F.) (Diptera: Tachinidae). Ann. Soc. Entomol. Bras. 14: 29-35.

Michael, P. J. 1981. Trichopoda-a tricky parasite. J. Agric., West. Aust. 22: 56-57.

Miller, R. L. 1928. Telenomous [sic] megacephalus Ashm., an egg parasite of the green pumpkin bug, Nezara viridula Linn., in Florida. Fla. Entomol. 12 $17-20$.

Mineo, G. 1979. Studies on the Scelionidae (Hym. Proctotrupoidea) IX. Material for a revision of the genus Gryon Hal., with description of 4 new species (G. austrafricanum, G. eremiogryon, G. laraichii, $G$. nicolai) and notes on other scelionids. Boll. Lab. Entomol. Agric. "F. Silvestri" 36: 234-265.

Ming-Dau, H., M. Siu-Jui, W. Wen-Nan \& P. ChihLung. 1974. The bionomics of Anastatus sp. and its utilization for the control of the lichee stink bug, Tessaratoma papillosa Drury. Acta Entomol. Sin. 17: 270-275 (in Chinese).

Myers, J. G. 1931. A preliminary report on an investigation into the biological control of West Indian insect pests. Empire Mktg. Board 42: 627-628.

Nakasuji, F., N. Hokyo \& K. Kiritani. 1966. Assessment of the potential efficiency of parasitism in two competitive scelionid parasites of Nezara viridula $\mathbf{L}$. (Hemiptera: Pentatomidae). Appl. Entomol. Zool. 1: 113-119.

Nishida, T. 1966. Behavior and mortality of the southern green stink bug Nezara viridula in Hawaii. Res Popul. Ecol. 8: 78-88.

Nixon, G. E. J. 1935 . A revision of the African Telenominae (Proctotrupoidea, Fam. Scelionidae). Trans. R. Entomol. Soc. Lond. 83: 73-103.

1936. Three new species of Telenominae (Hym. Proctotrupoidea, Scelionidae). Proc. R. Entomol. Soc. Lond. (B) 5: 131-134.

1937. Some Asiatic Telenominae (Hym., Proctotrupoidea). Ann. Mag. Nat. Hist. (10) 20: 444-475.

1966. New hymenopterous egg-parasites of Hemiptera on coffee (Proctotrupoidea, Scelionidae). Ann. Mag. Nat. Hist. 13: 535-538.

Noble, N. S. 1937. An egg parasite of the green vegetable bug. N. S. W. Agric. Gaz. 48: 337-341.

O'Conner, B. A. 1950. Trichopoda pennipes F. in Fiji and the British Solomon Islands. Agric. J. Dep. Agric. Fiji Isl. 21: 63-71.

Orr, D. B. 1985. Evaluation of Telenomus chloropus Thomson for biological control of the southern green stink bug, Nezara viridula (L.). M.S. thesis, Louisiana State Univ., Baton Rouge.
Orr, D. B., D. J. Boethel \& W. A. Jones. 1984. Parasitism of stink bugs in soybean fields in Louisiana, p. 782. In 17th Int. Congr. Entomol. Proc. (abstr.).

1985. Development and emergence of Telenomus chloropus and Trissolcus basalis (Hymenoptera: Scelionidae) at various temperatures and humidities. Ann. Entomol. Soc. Am. 78: 615-619.

Orr, D. B., J. S. Russin, D. J. Boethel \& W. A. Jones. 1986. Stink bug (Hemiptera: Pentatomidae) egg parasitism in Louisiana soybeans. Environ. Entomol. 15: $1250-1254$.

Panizzi, A. R. \& F. Slansky, Jr. 1985. Review of phytophagous pentatomids (Hemiptera: Pentatomidae) associated with soybean in the Americas. Fla. Entomol. 68: 184-214.

Paoli, G. 1933. Prodromo di entomologia agraria dela Somalia Italiana. Biblio. Agrar. Colon. 1931-1933, Firenze.

Paramonov, S. J. 1956. A revision of the Australian species of Cylindromyia Meigen and Saralba Walker (Tachinidae: Diptera). Aust. J. Zool. 4: 358-375 (not seen, vide Cantrell [1984]).

Powell, J. E. \& M. Shepard. 1982. Biology of Australian and United States strains of Trissolcus basalis, a parasitoid of the green vegetable bug, Nezara viridula. Aust. J. Ecol. 7: 181-186.

Rao, V. P., M. A. Ghani, T. Sankaran \& K. C. Mathur. 1971. A review of the biological control of insects and other pests in south-east Asia and the Pacific region. Commonw. Inst. Biol. Control Tech. Commun. 6 .

Riek, E. F. 1962. A new encyrtid genus parasitic on bug eggs. Proc. Linn. Soc. N. S. W. 87: 151-155.

Sabrosky, C. W. 1955. The interrelations of biological control and taxonomy. J. Econ. Entomol. 48: 710714.

Sales, F. M., J. R. McLaughlin, R. I. Sailer \& J. H. Tumlinson. 1978. Temporal analysis of the ovipositional behavior of the female egg parasitoid, Trissolcus basalis (Wollaston). Fitossanidade 2: 80-83.

Schmitz, G. 1978. Fam. Pentatomidae. Ann. Mus. R. Afr. Cent. (8, Sci. Zool.) 215: 367-391.

Schoene, W. J. \& G. W. Underhill. 1933. Economic status of the green stinkbug with reference to the succession of its wild hosts. J. Agric. Res. 46: 863866.

Servadei, A. 1967. Fauna d'Italia, vol. 9, Rhynchota (Heteroptera, Homoptera, Auchenorrhyncha). Ed. Calderini, Bologna.

Shahjahan, M. \& J. W. Beardsley, Jr. 1975. Egg viability and larval penetration in Trichopoda pennipes pilipes Fabricius (Diptera: Tachinidae). Proc. Hawaii. Entomol. Soc. 22: 133-136.

Shapiro, V. A., G. V. Guseva \& O. V. Kapustina. 1975. Comparative evaluation of biological properties of egg parasites Fam. Scelionidae, imported and USSR species, pp. 99-123. In G. V. Guseva \& V. A. Shcheretilnikova [eds.], Biological methods for plant protection. Proc. All-Union Sci. Res. Inst. Plant Protect. 44: 1-233 (translated for ARS-USDA and NSF, Washington, by Saad Publications, Karachi, Pakistan).

Silva, A. G. d'A., C. R. Goncalves, D. M. Galvao, A. J. L. Goncalves, J. Gomes, M. N. Silva \& L. Simoni. 1968. Quarto catálogo dos insetos que vivem nas plantas do Brasil-seus parasitas e predadores, Parte II, vol. 1. Min. Agric., Rio de Janeiro (not seen, vide Panizzi \& Slansky [1985])

Singh, O. P. \& R. R. Rawat. 1982. Some observations 
on the green stink bug, Nezara viridula Linn. on summer green gram crop at Jabalpur, Madhya Pradesh. Sci. Cult. 48: 108-109.

Singh, Z. 1973. Southern green stink bug and its relationship to soybeans. Metropolitan, Delhi.

Su, T. H. \& H. K. Tseng. 1984. The introduction of an egg parasite, Trissolcus basalis (Wollaston), for control of the southern green stink bug, Nezara viridula (L.) in Taiwan. J. Agric. For. 33: 49-54 (in Chinese, with English summary).

Szabó, J. B. 1981. In Hemipteren-Eiern lebende Telenominen aus der Turkei (Hymenoptera: Proctotrupoidea, Scelionidae). Folia Entomol. Hung. 42: 197-199.

Taiwan Agricultural Research Institute. 1984. Annual report 1983. Taichung Hsien, Taiwan (in Chinese).

Takano, S. 1956. Classification of and biological observations on Tachinidae, pp. 59-63. In Ann. Rep. Coop. Res. (Agric.), Ministry of Education, Tokyo (not seen, vide Hokkanen [1986])

Temerak, S. A. \& W. H. Whitcomb. 1984. Parasitoids of predaceous and phytophagous pentatomid bugs in soybean fields at two sites of Alachua County, Florida. Zeitschr. Angew. Entomol. 97: 279-282

Thames, W. H., Jr. 1954. Insect investigations. Fla Agric. Exp. Sta. Annu. Rep. 1954.

Thomas, J. W. 1972. Evaluation of Trissolcus basalis (Wollaston) as an egg parasite of Nezara viridula (L.). M.S. thesis, Louisiana State Univ., Baton Rouge.

Todd, J. W. \& D. C. Herzog. 1980. Sampling phytophagous Pentatomidae on soybean, pp. 438-478. In M. Kogan \& D. C. Herzog [eds.], Sampling methods in soybean entomology. Springer-Verlag, New York.

Todd, J. W. \& W. J. Lewis. 1976. Incidence and oviposition patterns of Trichopoda pennipes (F.), a parasite of the southern green stink bug, Nezara viridula (L.). J. Ga. Entomol. Soc. 11: 50-54.

Van der Vecht, J. 1933. De groote peperwants of semoenjoeng (Dasynus piperis China). Proefschr. Rijksuniv. Leiden.

van Emden, F. I. 1945. Keys to the Ethiopian Tachinidae. 1. Phasinae. Proc. Zool. Soc. London 114: 389436

Voegelé, J. 1961. Contribution à l'étude de la biologie des hyménoptères oophages des punaises des céréales au Maroc. Cah. Rech. Agron. 14: 69-70 (not seen, vide Hokkanen [1986]).

Watanabe, C. 1954. Discovery of four new species of Telenominae, egg-parasites of pentatomid and plataspid bugs, in Shikoku, Japan (Hymenoptera: Proctotrupoidea). Trans. Shikoku Entomol. Soc. 4: 17-22.

Whitfield, F. G. \& W. P. L. Cameron. 1932. The Sudan dura bug (Agonoscelis versicolor, F.). Bull. Wellcome Trop. Res. Lab., Entomol. Sect. 28: 1-21.

Wilson, F. 1960. A review of the biological control of insects and weeds in Australia and Australian New Guinea. Commonw. Inst. Biol. Control Tech. Commun. 1: 1-102.

1961. Adult reproductive behavior in Asolcus basalis (Hymenoptera: Scelionidae). Aust. J. Zool. 9: 739 751.

1963. The results of biological control investigations in Australia and New Guinea, pp. 112-123. In 9th Pac. Sci. Congr. Proc., 9.

Yadava, C. P., S. S. Lal \& C. A. R. Dias. $1982 . \quad$ New record of an egg parasite, Gryon sp. on Nezara viridula (L.). Entomon 7: 251.

Yukawa, J. \& K. Kiritani. 1965. Polymorphism in the southern green stink bug. Pac. Insects 7: 639-642.

Received for publication 2 March 1987, accepted 5 October 1987. 